\title{
KAJIAN KESEHATAN REPRODUKSI BENCANA DAN IDENTIFIKASI ANCAMAN, KAPASITAS, SERTA KERENTANAN BENCANA GEMPA BUMI DI DESA POTORONO, KECAMATAN BANGUNTAPAN, KABUPATEN BANTUL, DIY
}

\author{
Oleh: \\ Fitriana Putri Utami dan Oktomi Wijaya \\ Fakultas Kesehatan Masyarakat Universitas Ahmad Dahlan \\ E-mail: fitriana.utami@ikm.uad.ac.id

\section{Ringkasan}

Provinsi Daerah Istimewa Yogyakarta memiliki kerentanan terhadap ancaman bencana alam. Ancaman terbesar adalah gempa bumi dan letusan gunung berapi. Semua orang yang hidup dalam situasi darurat bencana berhak atas kesehatan termasuk kesehatan reproduksi. Pencegahan terjadinya risiko kerugian yang tinggi akibat bencana baik dalam sektor kesehatan maupun sektor lainnya dapat dilakukan dengan melakukan identifikasi risiko bencana. Identifikasi risiko bencana ini terdiri dari identifikasi ancaman bencana, kerentanan bencana, dan kapasitas bencana di tingkat desa.

Kajian kesehatan reproduksi bencana disampaikan dengan metode penyuluhan disertai diskusi interaktif. Identifikasi ancaman, kapasitas, dan kerentanan bencana menggunakan metode partisipatory. Peserta dipilih secara purposive. Data dianalisis secara deskriptif.

Peserta menyebutkan bahwa permasalahan kesehatan reproduksi yang dapat terjadi meliputi perasalahan kesehatan ibu dan anak, pelecehan seksual, dan penularan penyakit seksual yang diakibatkan oleh keadaan sarana prasarana pengungsian yang minim. Berdasarkan hasil identifikasi diketahui bahwa ancaman bencana gempa dapat menimbulkan kerentanan pada manusia khususnya bayi, anak-anak, lansia, dan penyandang cacat berupa luka sedang hingga kematian. Kerentanan pada infrastruktur berupa robohnya bangunan akibat struktur yang tidak kuat. Kapasitas bencana yang dimiliki desa berupa adanya forum kebencanaan dan pelatihan serta simulasi bencana yang mendukung adanya infrastruktur siaga bencana.

Ancaman gempa bumi dapat menimbulkan kerugian pada asset berisiko desa yang berupa manusia dan infrastruktur, namun pihak desa telah memiliki kapasitas / kekuatan pada seluruh aspek berisiko tersebut untuk meminimalisir kerugian yang muncul. Diharapkan aparat desa dapat meningkatkan kesiapsiagaan bencana dengan melakukan pemetaan risiko bencana desa secara berkesinabungan.

Kata kunci: Kesehatan Reproduksi Bencana, Identifikasi, Ancaman, Kerentanan, Kapasitas

\section{Abstract}

Special Province of Yogyakarta has vulnerability to natural disaster threat. The biggest threats are earthquakes and volcanic eruptions. All persons living in emergency situations are entitled to health including reproductive health. Prevention of high risk of losses caused by disasters both in the health sector and other sectors can be done by identifying disaster risks. This disaster risk identification consists of identification of disaster threats, disaster vulnerability, and disaster capacity at the village level. Disaster RH assessments are delivered by counseling methods along with interactive discussions. Identify disaster threats, capacities and vulnerabilities using participatory methods. Participants are chosen purposively. Data were analyzed descriptively. participants mentioned that reproductive health issues that may occur include issues of maternal and child health, sexual harassment, and sexual disease transmission caused by the condition of minimal evacuation facilities. Based on the results of the identification is known that the threat of earthquake disaster can cause vulnerability in humans, especially infants, children, the elderly, and people with disabilities in the form of injuries to death. Vulnerability to infrastructure 
is in the form of collapsed buildings due to structures that are not strong. The disaster capacity of the village consists of disaster and disaster forums and disaster simulations supporting the disaster preparedness infrastructure. the threat of an earthquake can cause losses to the village's risky assets in the form of people and infrastructure, but the village has the capacity strength in all these risky aspects to minimize the losses that arise. It is expected that village officials can improve disaster preparedness by conducting sustainable disaster risk mapping.

Keywords: Disaster Reproduction Health, Identification, Threat, Vulnerability, Capacity

\section{A. PENDAHULUAN}

Wilayah Indonesia merupakan gugusan kepulauan terbesar di dunia. Bangsa Indonesia perlu menyadari bahwa wilayah nusantara ini terletak di pertemuan 3 lempeng aktif dunia, lempeng Indo-Australia, Eurasia dan Pasifik. Menurut Sutikno (dalam Marfai et al., 2007), posisi Indonesia yang berada di pertemuan tiga lempeng ini menyebabkan wilayah Indonesia berpotensi terhadap ancaman bencana alam geologi seperti gempa bumi dan tsunami. Provinsi Daerah Istimewa Yogyakarta memiliki kerentanan terhadap berbagai ancaman bencana alam. Ancaman terbesar antara lain gempa bumi dan letusan gunung berapi. (Karnawati dkk, 2009).

Kabupaten Bantul tercatat sebagai kabupaten dengan jumlah bencana terbanyak di Provinsi Yogyakarta pada tahun 2003-2016, yaitu 35 kejadian bencana. Kejadian bencana terbesar yang menimpa Kabupaten Batul adalah bencana gempa bumi pada tahun 2006 dengan 12.026 korban terluka, 802.804 hilang, dan 4.134 meninggal dunia. Beberapa tahun belakangan ini juga telah terjadi kejadian bencana di Kabupaten Bantul, antara lain kejadian bencana kekeringan tahun 2014 mengakibatkan 25 orang menderita, banjir pada tahun 2015 yang mengakibatkan 130 orang terluka. Kasus gempa bumi di Bantul menunjukan wilayah yang rawan bencana justru terjadi di wilayah dengan tingkat kepadatan penduduk dan kepadatan pemukiman tinggi. Kecamatan Banguntapan merupakan kecamatan yang memiliki kepadatan penduduk tinggi dan termasuk wilayah rawan bencana. Selain itu, kecamatan Banguntapan juga masuk dalam peta rawan bencana akibat tingginya intensitas hujan. (BNPB, 2016a)

Semua orang, termasuk mereka yang hidup dalam situasi darurat bencana, berhak atas kesehatan. Salah satu aspek kesehatan yang penting dalam situasi bencana namun sering terlupakan adalah aspek kesehatan reproduksi. Banyak permasalahan kesehatan reproduksi yang terjadi antara lain tingginya angka kesakitan dan kematian ibu hamil saat melahirkan bayinya, tingginya angka kesakitan bayi dan balita saat kondisi darurat bencana, misalnya di lokasi pengungsian. Pelayanan kesehatan reproduksi merupakan hak bagi semua orang seperti yang dicanangkan pada ICPD 1994 maka diperlukan penyediaan layanan kesehatan reproduksi dalam situasi darurat bencana (IAWG, 2010).

Pencegahan terjadinya risiko kerugian yang tinggi akibat bencana baik dalam sektor kesehatan maupun sektor riil lainnya dapat dilakukan dengan melakukan identifikasi risiko bencana dilingkup desa. Identifikasi risiko bencana ini terdiri dari identifikasi ancaman bencana, kerentanan bencana, dan kapasitas bencana di tingkat desa. Berdasarkan pada uraian diatas, penulis selaku tim pangabdian masyarakat Fakultas Kesehatan Masyarakat Universitas Ahmad Dahlan disupport sepenuhnya oleh Lembaga Pengabdian Masyarakat Universitas Ahmad Dahlan melakukan kegiatan pengabdian kepada 
Diterbitkan oleh Lembaga Pengabdian kepada Masyarakat

Universitas Ahmad Dahlan Yogyakarta

masyarakat yang berjudul "Pelatihan Penyusunan Peta Risiko Bencana dan Kajian Kesehatan Reproduksi Bencana di Desa Potorono, Kecamatan Banguntapan, Bantul.” Kegiatan pelatihan ini bertujuan untuk membantu warga desa melakukan identifikasi risiko bencana sebagai upaya meminimalisir kerugian akibat bencana yang dapat muncul, serta memberikan pengetahuan kepada masyarakat terkait aspek kesehatan reproduksi dalam situasi bencana.

\section{B. METODE}

Peserta pada kegiatan ini adalah perwakilan masyarakat dari sembilan dusun di Desa Potorono, Banguntapan, Bantul, DIY. Pemilihan peserta dilakukan secara purposive dengan ketentuan setiap dusun di Desa Potorono diwakilkan oleh tiga orang warganya yang terdiri dari satu orang anggota forum pengurangan risiko bencana (FPRB), satu orang kader muhammadiyah, dan satu orang perangkat dusun. Dari 27 orang yang diundang sebagai peserta, satu orang tidak berpartisipasi sehingga didapatkan 26 peserta yang mengikuti kegiatan pengabdian masyarakat selama dua hari pada tanggal 20-21 Mei 2017.

Metode yang digunakan dalam kegiatan pengabdian masyarakat ini adalah metode pendidikan masyarakat disertai dengan praktik. Kajian kesehatan reproduksi dalam situasi bencana disampaikan dengan metode penyuluhan disertai diskusi interaktif dengan peserta. Identifikasi ancaman, kapasitas, dan kerentanan bencana disampaikan dengan metode partisipatory, peserta melakukan penilaian pada ancaman, kapasitas, dan kerentanan bencana yang dimiliki oleh desa mereka secara mandiri, pelatih bertindak sebagai fasilitator. Data yang didapat dari hasil pengabdian masyarakat ini dianalisis secara deskriptif.

\section{HASIL}

\section{Karakteristik peserta}

Peserta pada kegiatan pengabdian masyarakat ini sebanyak 26 orang didominasi peserta laki-laki. Mayoritas peserta berusia 51-60 tahun (33,9\%) dengan tingkat pendidikan terakhir adalah SMA $(77,1 \%)$. Karakteristik peserta secara lebih rinci dapat dilihat pada table 1 .

\begin{tabular}{|l|c|c|}
\hline Karakteristik & f & Persentase (\%) \\
\hline Jenis Kelamin & 22 & 84,6 \\
Laki-laki & 4 & 15,4 \\
Perempuan & 2 & \\
\hline Usia & 2 tahun & 7,6 \\
$11-20$ tahun & 3 & 11,5 \\
$21-30$ tahun & 6 & 23,1 \\
$41-50$ tahun & 7 & 26,9 \\
$51-60$ tahun & 8 & 30,9 \\
\hline Pendidikan Terakhir & &
\end{tabular}




\begin{tabular}{|l|c|c|} 
Tidak tamat SD & 1 & 3,8 \\
SD & 1 & 3,8 \\
SMP & 3 & 11,5 \\
SMA & 20 & 77,1 \\
Pendidikan Tinggi & 1 & 3,8 \\
\hline
\end{tabular}

Tabel 1. Karakteristik peserta pelatihan

\section{Kajian Kesehatan Reproduksi Bencana}

Kajian kesehatan reproduksi dalam situasi bencana membahas menganai masalah kesehatan reproduksi yang dapat muncul ssaat bencana, penyebab masalah tersebut muncul, dan cara pencegahan terjadinya masalah tersebuut. Pada sesi ini, peserta diminta untuk berdiskusi menyebutkan permasalahan kesehatan reproduksi apa saja yang dapat terjadi saat bencana dan penyebab dari permasalahan tersebut.

Hasil diskusi antar peserta mennyebutkan bahwa permasalahan kesehatan reproduksi yang dapat muncul saat bencana antara lain ibu yang melahirkan di pengungsian, ibu hamil yang keguguran di pengungsian, bayi atau balita yang sakit di pengungsian, tindak pelecehan seksual, dan penularan penyakit seksual. Analisis peserta terhadap penyebab terjadinya permasalahan tersebut antara lain dikarenakan oleh lokasi tidur di pengungsian yang bercampur antara laki-laki dan perempuan, kurangnya tenaga medis dan alat-alat medis di pengungsian, sanitasi lokasi pengungsian yang buruk, serta toilet yang bercampur antara perempuan dan laki-laki.

\section{Identifikasi ancaman bencana gempa}

Identifikasi ancaman dimulai dengan peserta memilih ancaman prioritas bencana yang dapat terjadi di desa mereka. Penentuan prioritas ini dilakukan dengan mengidentifikasi jenis bencana yang dapat terjadi di desa mereka lalu mengisi besarnya kemungkinan bencana tersebut terjadi dan dampak yang ditimbulkan dengan skor 1-4. Semakin tinggi skor yang diberikan makan semakin besar kemungkinan bencana dan dampak yang dapat terjadi. Pada penentuan ancaman bencana ini warga meengidentifikasi bencana yang mungkin terjadi di Desa Potorono adalah bencana banjir, angin putting beliung, gempa, dan kebakaran. Dalam penentuan prioritas peserta memilih bencana dengan ancaman terbesar adalah bencana gempa. Prioritas ancaman bencana dapat dilihat pada table 2 .

\begin{tabular}{|l|l|l|l|}
\hline \multicolumn{1}{|c|}{ Ancaman } & Kemungkinan terjadi & Dampak & $\begin{array}{c}\text { Total Nilai } \\
\text { (kemungkinan terjadi } x \\
\text { dampak) }\end{array}$ \\
\hline Banjir & 1 & 2 & 2 \\
\hline Angin puting beliung & 2 & 3 & 6 \\
\hline Gampa bumi & $\mathbf{4}$ & $\mathbf{4}$ & $\mathbf{1 6}$ \\
\hline Kebakaran & 3 & 3 & 9 \\
\hline
\end{tabular}

Tabel 2. Prioritas ancaman bencana 
Diterbitkan oleh Lembaga Pengabdian kepada Masyarakat

Universitas Ahmad Dahlan Yogyakarta

Setelah peserta menentukan bencana gempa sebagai prioritas bencana yang dapat terjadi. Selanjutnya peserta mengidentifikasi jenis ancaman bencana gempa itu sendiri. Peserta mengidentifikasi jenis ancaman yang terdiri dari factor penyebaab, factor perusak, tanda peringatan, frekuensi, dan durasi. Hasil identifikasi ancaman gempa bumi dapat dilihat pada tabel 3 .

\begin{tabular}{|l|l|}
\hline Karakter & Keterangan \\
\hline Faktor penyebab & Gempa vulkanik \\
& Gempa tektonik \\
\hline Faktor perusak & Struktur bangunan tidak kuat (rawan roboh) \\
& SDM kurang \\
& Ulah Manusia \\
\hline Tanda peringatan & Langit gelap \\
\hline Kecepatan hadir & Tidak pasti \\
\hline Frekuensi & Tidak pasti \\
\hline Durasi & 60 detik \\
\hline Lokasi & Seluruh desa \\
\hline
\end{tabular}

Tabel 3. Identifikasi ancaman bencana gempa

\section{Identifikasi Kerentanan Bencana Gempa}

Pada identifikasi kerentanan bencana ini, peserta diminta untuk menilai asset berisiko yang rentan terkena dampak dari bencana gempa. Asset berisiko ini terdiri dari manusia dan infrastruktur / bangunan. Pengidentifikasian kerentanan dilakukan dengan menilai asumsi bentuk risiko pada asset dan kelemahan penyebab asset berisiko. Hasil identifikasi kerentanan bencana gempa dapat dilihat pada tabel 4 .

\begin{tabular}{|l|l|l|}
\hline Aset Berisiko risiko & $\begin{array}{l}\text { Kelemahan penyebab } \\
\text { asset berisiko } \\
\text { pada aset }\end{array}$ \\
\hline $\begin{array}{l}\text { Manusia } \\
\text { (Bayi/anak } \\
\text { cacat) }\end{array} \quad$ kecil,lansia, & $\begin{array}{l}\text { Meningal luka sedang, } \\
\text { luka berat }\end{array}$ & $\begin{array}{l}\text { Kemampuan fisik yang } \\
\text { terbatas }\end{array}$ \\
\hline $\begin{array}{l}\text { Fisik I infrastruktur/ } \\
\text { bangunan }\end{array}$ & $\begin{array}{l}\text { Rumah, masjid, dan } \\
\text { sekolah rusak, jalan retak, } \\
\text { jembatan roboh }\end{array}$ & $\begin{array}{l}\text { Struktur bangunan yang } \\
\text { tidak kuat }\end{array}$ \\
\hline
\end{tabular}

Tabel 4. Identifikasi kerentanan bencana gempa

\section{Identifikasi Kapasitas Bencana Gempa}

Identifikasi kapasitas bencana merupakan langkah untuk menilai kekuatan yang dimiliki oleh desa dalam mengurangi risiko bencana yang dapat muncul. Identifikasi kapasitas ini terdiri dari penilaian kekuatan yang tersedia pada asset berisiko. Hasil identifikasi kapasitas bencana gempa dapat dilihat pada tabel 5 .

\begin{tabular}{|l|l|l|}
\hline Aset Berisiko & \multicolumn{3}{|c|}{ Kekuatan tersedia (untuk mengurangi risiko bencana) } \\
\hline $\begin{array}{l}\text { Sumber } \\
\text { Manusia }\end{array}$ & $\begin{array}{l}\text { Organisasi Forum Pengurangan Risiko Bencana } \\
\text { (FPRB) sebanyak 30 orang }\end{array}$
\end{tabular}




\begin{tabular}{|l|l|} 
& -Peningkatan SDM dalam tanggap bencana \\
& -Pelatihan P3K 60 orang tahun 2014 \\
& -Simulasi bencana tahun 2016 \\
& -Sosialisasi kebencanaan 2 kali dalam setahun \\
& -Sosialisasi kepada masyarakat menghadapi bencana \\
\hline Alam / lingkungan & - Perbaikan daerah rawan bencana \\
\hline Fisik / infrastruktur & - Bangunan tahan gempa \\
& - Dapur umum disesuaikan \\
& - Pengadaan alat-alat kebencanaan dian di lapangan \\
& - Asuransi \\
& - Pembuatan jalur evakuasi \\
& - Tersedianya lokasi pengungsian \\
& - Santunan korban bencana \\
\hline
\end{tabular}

Tabel 5. Identifikasi kapasitas bencana gempa

\section{PEMBAHASAN}

Issu mengenai kesehatan reproduksi dalam situasi bencana merupakan issue yang masih sering dilupakan oleh masyarakat, dalam situasi bencana yang kacau sangat rentan untuk terjadi permasalahan keesehatan reproduksi khususnya pada wanita dan anak-anak. Hasil identifikasi yang dilakukan oleh peserta pelatihan pada permasalahan kesehatan reproduksi dalam situasi bencana sama seperti pernyataan IAWG tahun 2010 yaitu bahwa di lokasi pengungsian bencana juga marak terjadi pelecehan seksual akibat minimnya fasilitas pengungsian dan tak ada sekat antara pengungsi laki-laki dan perempuan. Pelecehan seksual ini dapat meningkatkan risiko kehamilan tidak diinginkan dan penularan HIV/AIDS serta Infeksi Menular Seksual lainnya. (IAWG, 2010).

Prioritas bencana yang dipilih oleh peserta adalah bencana gempa, hal ini dinilai tepat karena menurut Kramer secara geografis Indonesia terletak pada rangkaian cincin api yang membentang sepanjang lempeng pasifik yang merupakan lempeng tektonik paling aktif di dunia. Zona ini memberikan kontribusi sebesar 6ector 90\% dari kejadian gempa di bumi dan sector semuanya merupakan gempa besar di dunia (Kramer dalam BNPB, 2016b). Beberapa gempa besar telah terjadi dalam 10 tahun terakhir dan mengakibatkan kehilangan jiwa serta kerugian material yang mempengaruhi sector ekonomi dan pembangunan.(BNPB, 2016b)

Hasil identifikasi ancaman, kerentanan, dan kapasitas bencana desa yang dilakukan oleh peserta pelatihan ini merupakan langkah awal dalam melakukan pemetaan risiko bencana gempa. Dalam upaya untuk mengurangi risiko bencana gempa bumi di Indonesia, langkah pertama yang terpenting untuk dilakukan adalah melakukan pemetaan risiko bencana gempa bumi di seluruh wilayah di Indonesia. Peta ini diperlukan untuk mengidentifikasi wilayah-wilayah dengan risiko gempa yang tinggi. Dengan diketahuinya wilayah-wilayah dengan risiko gempa yang tinggi, antisipasi untuk mengurangi dampak 
Diterbitkan oleh Lembaga Pengabdian kepada Masyarakat

Universitas Ahmad Dahlan Yogyakarta

bencana yang mungkin timbul di wilayah-wilayah tersebut dapat dilakukan sedini mungkin. (BNPB, 2016b)

\section{E. KESIMPULAN DAN SARAN}

Kajian kesehatan reproduksi dalam situasi bencana, peserta menyebutkan bahwa permasalahan kesehatan reproduksi yang dapat terjadi meliputi perasalahan kesehatan ibu dan anak, pelecehan seksual, dan penularan penyakit seksual yang diakibatkan oleh keadaan sarana prasarana pengungsian yang minim. Berdasarkan hasil identifikasi pada segi ancaman, kerentanan, dan kapasitas bencana diketahui bahwa ancaman gempa bumi dapat menimbulkan kerugian pada asset berisiko desa yang berupa manusia dan infrastruktur, namun pihak desa telah memiliki kapasitas / kekuatan pada seluruh aspek berisiko tersebut yang dapat digunakan untuk meminimalisir kerugian yang muncul akibat bencana. Diharapkan aparat desa bekerjasama dengan organisasi masyarakat setempat dapat meningkatkan kesiapsiagaan bencana dengan melakukan peemetaan risiko bencana desa secara berkesinabungan dari hasil identifikasi ancaman yang telah dilakukan.

\section{DAFTAR PUSTAKA}

Inter-agency Working Group on Reproductive Health in Crisis. Buku Pedoman Lapangan Antar-lembaga Kesehatan Reproduksi dalam Situasi Darurat Bencana. 2010. Diunduh dari http://iawg.net/wp-content/uploads/2016/07/IAFM-Bahasaversion.pdf (pada tanggal 28 Februari 2017, pukul 19.30 WIB)

Badan Nasional Penanggulangan Bencana. Data dan Informasi Bencana Indonesia. 2016. Diunduh dari http://dibi.bnpb.go.id/data-bencana/statistik (pada tanggal 02 Maret 2017, pukul 07.00WIB)

Badan Nasional Penanggulangan Bencana. 2016b. Risiko Bencana Indonesia. Deputi Bidang Pencegahan dan Kesiapsiagaan. Jakarta

Inter-agency Working Group on Reproductive Health in Crisis. Buku Pedoman Lapangan Antar-lembaga Kesehatan Reproduksi dalam Situasi Darurat Bencana. 2010. Diunduh dari http://iawg.net/wp-content/uploads/2016/07/IAFM-Bahasaversion.pdf (pada tanggal 28 Februari 2017, pukul 19.30 WIB)

Karnawati D Pramumijoyo S, Husein S, Andayani B, \& Burton PW, 2010, Development of community based earthquake hazard mapping - A pilot study in Bantul, Yogyakarta Province,

Indonesia. In IRP-ADRC, Recovery Status Report No. 01 The Yogyakarta and Central Java Eathquake 2006, 2009 pp.67-80

Marfai, M.A., King, L., Singh, L.P., Mardiatno, D., Sartohadi, J., Hadmoko, D.S., Anggraini, D., 2008, Natural Hazards in Central Java Province, Indonesia: an overview. Environ Geol 56:335-351. 
